\title{
Investigation Action Against Children Who Are Circulating Pharmaceuticals Stocks That Does Not Have Permission In Jurisdictions Police Resort (Polres) Kudus
}

\author{
Indra Narotama ${ }^{1}$ and Lathifah Hanim ${ }^{2}$
}

Abstract. This research to know the legal basis for investigation of cases of children who distribute pharmaceutical preparation which does not have a marketing authorization, the implementation of the investigation on the case of children who distribute pharmaceutical preparation which does not have a marketing authorization in the territory of the police station of the Kudus, barriers and solutions in the implementation of the investigation on the case of children who circulate preparations pharmacy that does not have a marketing authorization in the territory of the Kudus Police.

The method used is empirical juridical methods. Specifications research used the descriptive analysis. Data was collected by interviewing the parties involved in research, direct observation and recording of documents.

The results showed that the basic legal basis for investigation of trafficking cases and abuse of pharmaceutical preparations without a marketing authorization is Act No.36 of 2009 on Health, which sentencing criminal offense trafficking and abuse of pharmaceutical preparations without a marketing authorization provided for in Article 197, it refers to the the provisions of Article 106 paragraph (1) in the form of pharmaceutical preparations and medical devices can only be released after obtaining marketing authorization. The process of investigation of the case of children who distribute pharmaceuticals do not have a marketing authorization in the territory of the Kudus Police have been done by the procedural law in Indonesia, namely the Criminal Code, it is proved to have been implemented procedures Investigators action in the process of investigation. The process of investigation is also under the provisions of Article 189Undang Act No. 36 of 2009 on Health and Act No. 3 of 1997 on Juvenile Court and the provisions of Article 82 of Act No. 23 of 2002 on Child Protection. Barriers faced by investigators Kudus Police in carrying out investigation on the case of children who distribute pharmaceuticals do not have a marketing authorization in the jurisdiction of the Kudus Police is limited both the quantity and quality of human resources of law enforcement officers who understand the case for children, operating costs, low awareness of the witness in attending the examination process, the lack of legal awareness of the society and time specified in the investigation of cases children are very little, while filing must be submitted as soon as possible.

Keywords: Investigation; Children; Pharmacy Circulation Without Permission.

\section{Introduction}

The development of science in Indonesia to bring the community in order to live a fastpaced and practice. The achieved in the field of science and technology can bring a

\footnotetext{
${ }^{1}$ Student Mater of Law, Unissula, Email: indrakresna5587@gmail.com

${ }^{2}$ Faculty of Law Universitas Islam Sultan Agung
} 
country on the welfare and prosperity for people. But undeniable advances in technology and science make irregularities and social. In economic crime and can be seen in developed countries or developing country, the type of fraud and crime more streamlined.

Health Sciences is one discipline that experienced the fastest growth today as well as the development of science in the field of health criminal acts. The action occurring in the fields of health sciences, among others: malpractice, counterfeiting, trafficking and abuse of drugs without permission and transplantation of human organs. Health problems are a serious concern in all countries, both developed and developing, because health is one of the factors that determine the progress of a country and a human right. The State has an obligation to its people to provide health care services and establish rules of law relating to the protection of health. In layman's health can mean the absence of disease. According to WHO's health is a state of being of body, soul and social enable everyone to live socially and economically productive. ${ }^{3}$

Medical law and health law was introduced in Indonesia with the formation of a study group for Legal Medicine at the University of Indonesia on November 1, 1982 in Cipto Mangunkusumo Hospital by several doctors and Bachelor of Laws. $^{4}$

Based on the opinions mentioned above, to children convicted of crimes should still be protected and wellbeing, even though conditions in children has been sentenced to criminal sanctions. So in the interest of the child is required an appropriate policy, especially within the framework of criminal sanctions against him.

Still fresh for remember on September 12, 2017, approximately $01.00 \mathrm{pm}$ in the Garden Gondang Manis has secured one on behalf of the Civil Village Maulana Bin Kamaludin Officer Sat Sabhara Police Kudus on deeds consuming liquor, after a search of the Civil Village Maulana Bin Kamaludin, found evidence of four (4) tablets yellow logo DMP are packed in plastic clips included in the jacket belonged to the Civil Village Maulana Bin Kamaludin, hereinafter Officer Sat Sabhara Police Kudus bestow brothers Village Maulana Bin Kamaludin and any evidence to the Member Sat Resnarkoba Police Ghost. After interrogation of the Civil Village Maulana Bin Kamalaudin that drug bearing the DMP obtained on the administration of the Civil Wahyu Budi Utomo Bin Nur Yusuf, 17 years, then clerk put through the arrest of the suspect Mr. Wahyu Budi Utomo Bin Nur Yusuf on Tuesday, September 12, 2017, and further suspects were taken to the police station to the Kudus of inquiry and investigation process. ${ }^{5}$

Based on the problems described above, the authors are interested in doing research in the form of legal writing and discuss it in the form of a thesis entitled " Investigation Action Against Children Who Are Circulating Pharmaceuticals Stocks That Does Not Have Permission In Jurisdictions Police Resort (Polres) Kudus ".

\footnotetext{
${ }^{3}$ Titon Slamet Kurnia, Hak Atas Drajat Kesehatan Optimal Sebagai HAM di Indonesia, Alumni, Bandung, 2007, p. 13

${ }^{4}$ Amri Amir, Bunga Ranpai Hukum Kesehatan, Widya Medika, Jakarta, 1997, p. 2

${ }^{5}$ Preriset in Kudus Police October $4^{\text {th }} 2018$
} 


\section{Research Methods}

The method used is qualitative analysis, namely data obtained through fieldwork and research literature then arranged systematically, and then analyzed qualitatively to achieve clarity issues to be discussed. The data is then analyzed using a theoretical and interpretive positive law which has been poured and then deductively conclude to address existing problems. ${ }^{6}$

\section{Results and Discussion}

\subsection{Investigation of the Basic Law of the Case of Children Circulate Pharmaceucals That Do Not Have Permission Marketing Authorization}

In the case of children who circulate the investigation pharmaceutical preparation which does not have a marketing authorization is the responsibility of the offenses he was doing. Strictly speaking, that accounted for that person is did. The responsibility of criminal offenses in case is a mechanism established by the criminal law to react to a breach of the agreement refuse an act, manifested in the form of prohibition (and threats by criminal) for such actions. ${ }^{7}$

The nature of the special law against that is the nature of the law against the written part of the formulation of the offense. According to Article 197 of Act No. 36 of 2009 on Health, the formulation contained in this article is any person who intentionally produce or distribute pharmaceutical and or / medical devices that do not have a marketing authorization referred to in Article 106 paragraph (1), namely pharmaceutical preparations and medical devices only can be released after obtaining marketing authorization.

In this case the authors give examples of cases in the region of Police Kudus on September 12, 2017, approximately at 01.00 pm in the Garden Gondang Manis has secured one on behalf of the Civil Village Maulana Bin Kamaludin by officers Sat Sabhara Police Kudus on deeds consuming liquor, after conducted a search of the Civil Village Maulana Bin Kamaludin, found evidence of four (4) tablets yellow logo DMP are packed in plastic clips included in the jacket belonged to the Civil Village Maulana Bin Kamaludin, hereinafter Officer Sat Sabhara Police Kudus bestow brothers Village Maulana Bin Kamaludin and any evidence to the Member Sat Resnarkoba Kudus Police. After interrogation of the Civil Village Maulana Bin Kamalaudin that drug bearing the DMP obtained on the administration of the Civil Wahyu Budi Utomo Bin Nur Yuduf, 17 Years, then clerk put through the arrest of the suspect Mr. Wahyu Budi Utomo Bin Nur Yusuf on Tuesday, September 12, 2017 and subsequent suspects were taken to the police station to the Kudus of inquiry and investigation process.

Investigators interview based on officer in Kudus Police, Bripka Hendri Agus A. ${ }^{8}$ The background of this problem is less supervision from parents when a suspect is outside the home, as well as the suspect wanted to try and enjoy the DMP logo yellow tablets

\footnotetext{
${ }^{6}$ Ibid, p.119

${ }^{7}$ Chairul Huda, Tiada Pidana Tanpa Kesalahan Menuju kepada Tiada Pertanggung Jawaban Pidana Tanpa Kesalahan, Prenada Media, Jakarta, 2006, p. 47

${ }^{8}$ Interview of the Kudus Police Investigator Bripka Hendri Agus A On December 18, 2018
} 
that are bought from a friend who just knew. After trying the suspect's heart happy and fly, so the suspect to buy another for their own consumption and sold to her friends who need so that suspects can gain self-sufficient remedy. This happens due to lack of knowledge about the law, as well as the age of the suspect is still relatively young children and the quality of faith which is very less as well as low self control and do not think about as a result of his actions.

Results of interviews with Mr. Sukadi as Polres Kudus Resnarkoba Adj. ${ }^{9}$ Please be informed that on Tuesday, September 14, 2017, has started investigation of criminal any person who intentionally produce or distribute pharmaceutical and / or medical devices that do not have a marketing authorization or any person who intentionally produce or distribute pharmaceutical and / or medical equipment that does not meet the standards and / or requirements of safety, efficacy or usefulness and quality, which occurred on Monday, September 11, 2017, approximately $21.30 \mathrm{am}$, at the point participate Village Wergu Kulon city of Kudus, as referred to in Article 197 or Article 196 of Act No. 36 of 2009 on Health.

According to the provisions of Article 197 of Act 36 of 2009 on Health, the formulation contained in this article is any person who intentionally produce or distribute pharmaceutical and or / medical devices that do not have a marketing authorization referred to in Article 106 paragraph (1), namely pharmaceutical preparations and medical devices can only be released after obtaining marketing authorization.

Criminal provisions in the aforementioned article in the form of producing pharmaceutical drugs without a marketing authorization is 15 years in prison and a fine of 1.5 billion rupiah and for which circulate punishable by 10 years in prison and a fine of 1 billion rupiah.

The legal basis for case investigation trafficking and abuse of pharmaceutical preparations without a marketing authorization is Act No.36 of 2009 on Health, which manaketentuan sentencing criminal offense trafficking and abuse of pharmaceutical preparations without a marketing authorization provided for in Article 197, it refers to the provisions of Article 106 paragraph (1) in the form of pharmaceutical preparations and medical devices can only be released after obtaining marketing authorization.

\subsection{Investigation Case Against Children Who Circulate Pharmaceucals That Do Not Have Permission Marketing Authorization In Area Kudus Police Juridiction}

In accordance with Article 1 paragraph 2 Criminal Code stated that the investigation is a series of actions Investigators in the case and in the manner stipulated in this Law to search for and collect evidence with evidence that shed light on criminal activity and in order to find the suspects. ${ }^{10}$

Analysis Case Against investigation of a child who distribute pharmaceutical preparation which does not have a marketing authorization in the territory of the police station of the Kudus that there has been a criminal offense any person intentionally produce or circulating pharmaceutical preparation which does not have a

\footnotetext{
${ }^{9}$ Interviews with Mr. Sukadi as Kudus Police Resnarkoba Adj.Date December 18, 2018

${ }^{10}$ Hari Sasangka \& Lily Rosita, 2003, Hukum Pembuktian dalam Perkara Pidana, Bandung: Mandar Maju, p. 17.
} 
marketing authorization or any person who intentionally produce or distribute pharmaceutical preparations which are not standards exist or the requirements of safety, efficacy and quality, which is done by the suspect Wahyu Budi Utomo Bin Nur Yusuf, born in Demak, 12 September 1999 (age 18), Gender male, Islam, Employment Labor, Citizenship Indonesia / Java, Latest Education junior class 1 (completed), address Luntas hamlet, village Mlatiharjo RT.01 RW.03 Gajah District of Demak, where on Tuesday, September 12, 2017, approximately at 01.00 am at Oasis Park Village succession Gondangamanis District of Bae Kudus have secured witnesses II (two) Village Maulana bin Kamaludin by witness I (one) Syaifun Nuha bin Mustafa Kam al and Members Sabhara Police Kudus on deeds consuming liquor, after conducting a search for witnesses II (two) Village Maulana Bin Kamaludin and found evidence of four (4) tablets yellow logo DMP are packed in plastic clips are included in the jacket Witness II (two) Village Maulana bin Kamaludin, then bestow the Kudus Police officer witness Sabhara II (two) Village Maulana bin Kamaludin and any evidence over to Sat Resnarkoba Kudus Police. After interrogation Witness II (two) Village Maulana Bin Kamaludin explains that the pills yellow logo DMP obtained on giving of suspects Wahyu Budi Utomo Bin Nur Yusuf where the suspect Wahyu Budi Utomo Bin Nur Yusuf also sells pharmaceutical preparations that the witness VI (six) Muhamad Bald Alia Bin Faris Alghofar Ward 2 (two) packets containing sixteen (16) tablets for Rp. 40.000, (forty thousand rupiah) on Monday, 11 September 2017 approximately at 21:30 pm at the food stall village Wegu Kulon Sub City Kudus, both suspects Wahyu Budi Utomo bin Nur Yusuf does not have the expertise or knowledge of pharmacy or medicine so do not know the efficacy or usefulness and quality contained in a yellow pill DMP logo. Furthermore, the suspect was taken to Kudus Police Office to the process of inquiry and investigation. ${ }^{11}$

On the information of the public and have diamankannya Kamaludin Bin brother Maulana village after being searched was found tablet of DMP logo, Sat member Resnarkoba make police report to model A.

That at the time of securing and ransacked Mr. Maulana bin Kamaludin the village occurred originated from premises public information report of model $A$.

In this investigation the police play a role, although attorney who will eventually use the results that have been obtained it for the benefit of the accused to the Court of Justice demanding. However, it is clear that can not be done alone for it. Therefore the assistance of other officials. For the successful prosecution of the work it is only logical if the prosecutor can oversee, coordinate and give instructions to the officials who assist investigators in gathering such evidence. ${ }^{12}$

The process of investigation of the case of children who distribute pharmaceuticals do not have a marketing authorization in the territory of the Kudus Police have been done by the procedural law in Indonesia, namely the Criminal Code, it is proved to have been implemented procedures Investigators action in the process of investigation. The process of investigation is also under the provisions of Article 189 Act No. 36 of 2009 on Health and Act No. 3 of 1997 on Juvenile Court and the provisions of Article 82 of Act No. 23 of 2002 on Child Protection.

\footnotetext{
${ }^{11}$ Interview of the Kudus Police Investigator Bripka Hendri Agus A On December 18, 2018

${ }^{12}$ Ibid, p. 26.
} 


\subsection{Obstacles And Solutions In Case Investigation Against Children Who Circulate Pharmaceucals That Do Not Have Permission Marketing Authorization In Area Kudus Police Juridiction}

Obstacles encountered in frame investigation on the case of children who distribute pharmaceutical preparation which does not have a marketing authorization as the result winterview with several stakeholders, certainly experienced or there are some problems in the field.

The imbalance between the number of officers with the number of cases, often leads to the abandonment of some cases up only until the investigation stage. Insufficient numbers of officers police on duty at Sat Resnarkoba Polres Kudus only 14 Members, given the issues dealt with are very diverse, certainly not just a case of the Case of Children Circulate of Pharmaceutical Products That Do Not Have a circulation permit only, but also of criminal cases related to narcotics. Number of Officers that there were comparable with the vast range of areas addressed in the region Sat Resnarkoba Polres Kudus. $^{13}$

Investigators in the act of detention, in practice, according to Mr Sukadi as Adj Resnarkoba Kudus Police,basic consideration of the arrest of the child has not been understood properly Investigator. In the early stages of investigation, investigators were unable to finish on tort for children who have done diversion so should proceed to trial, lack of human resources owned by the Police of the Kudus that report handling criminal offenses committed by children who committed the crime of handling very time-consuming and can not be implemented optimally.

Facilities and infrastructure are the constraints related to the protection of the Kudus Police suspect a child is weak supervision and security at the entrance or exit lanes Sat Resnarkoba building, this makes unauthorized parties easy to enter the building without permission Sat Rsnarkoba or ID Card. In connection with another obstacle to infrastructure is the unavailability of special detention place for a child in custody for the investigation process. Another constraint for Space Investigator is the absence soundproof room divider or a closed room. Sat Resnarkoba Polres Kudus only had one room that is closed while the tables for the investigation process there is no bulkhead. The lack of understanding of the juvenile justice law does not create the impression of professionalism and indications of malpractice in the criminal justice system. Exaggerated big deal of problem children a criminal offense for public consumption make it appear as though the public never made a mistake or contribute to errors made by the child.

Their 30-day time limit in accordance with Article 44 paragraph (4) of the Act for a Juvenile Court investigator shall submit the case file to the public prosecutor suspects child make Investigators would not want to make the effort of investigation as soon as possible to avoid exceeding the provisions above. Though the complexity of the case and a long vetting process also affect the investigation process. This sometimes makes trouble doing Degree Case investigator or diversion, for Case Holds do not only involve

\footnotetext{
${ }^{13}$ Interview Mr. Sukadi as Kudus Police Resnarkoba Adj.Date December 18, 2018
} 
an element of Police, but the people and the Government, so that a relatively short time and the number of cases that occurred resulting in low performance of law enforcement officers.

Its proportional to the length of the investigation process as an example constrained by low awareness of the witnesses for examination and plus there is limited operational costs make the investigation process at a slow pace.

Efforts are being made with coordination among units in Sat Resnarkoba, with coordination will help reduce the constraints associated with the limited number of personnel. Additionally attempted cross-subsidy system officers are not on duty investigations and investigations to help control and investigation suspect a child if they meet the requirements in accordance with applicable regulations. But still had to coordinate with Child Unit Investigator PPA. Efforts are being made are also not only in quantity, but also quality. Ability and knowledge of child protection investigators should be improved. Through training and collaboration with the National Commission for Child Protection and Child observer NGO, investigators can better understand the issue of child protection.

Police Kudus conducted in solutions facing infrastructures is their plan to change the special room case children become separated from that room Sat Resnarkoba building. The hope with the removal, UPPA have its own building, considering the limited area of the room, UPPA can increase the number of personnel to have special facilities for children such as special detention and investigation closed room. The absence of special detention room a child, the other alternative is used police leave their children at shelters, NGOs and local government-owned or Dinsos.

Solutions made to overcome this problem is the law enforcement authorities such as the Police Child Protection Committee, as well as NGOs should provide insight to the public by means of socialization related to child protection, but it also socialization to do with the transfer of information through Public Media to provide education child protection is done by the National Commission through the media.

\section{Closing}

\subsection{Conclusion}

- The legal basis for case investigation trafficking and abuse of pharmaceutical preparations without a marketing authorization is Act No.36 of 2009 on Health, which sentencing criminal offense trafficking and abuse of pharmaceutical preparations without a marketing authorization provided for in Article 197, it refers to the provisions of Article 106 paragraph (1) in the form of pharmaceutical preparations and medical devices can only be released after obtaining marketing authorization.

- The process of investigation of the case of children who distribute pharmaceuticals do not have a marketing authorization in the territory of the Kudus Police have been done by the procedural law in Indonesia, namely the Criminal Code, it is proved to have been implemented procedures Investigators action in the process of investigation. The process of investigation is also under the provisions of Article 189 
Act No. 36 of 2009 on Health and Act No. 3 of 1997 on Juvenile Court and the provisions of Article 82 of Act No. 23 of 2002 on Child Protection.

- Barriers faced by investigators Kudus Police in carrying out investigation on the case of children who distribute pharmaceuticals do not have a marketing authorization in the jurisdiction of the Kudus Police is limited both the quantity and quality of human resources of law enforcement officers who understand the case for children, operating costs, low awareness of the witness in attending the examination process, the lack of legal awareness of the society and time specified in the investigation of cases children are very little, while filing must be submitted as soon as possible.

\subsection{Suggestion}

- For the Government to try to further analyze the factors that cause trafficking and abuse of pharmaceutical preparations without permission, so that there is a common perception of the causes of trafficking and abuse of pharmaceutical preparations without permission. Thus the solutions will be reached who are also of the same nature from the central level to the regions.

- For law enforcement officials, especially Police in order to improve HR Investigators by conducting debriefing form of education or specialized training to child investigators, so that investigators in handling the case of a child can take steps right and systematic in taking any decision so that the implementation is done optimally and do not hesitate,

- For society in general are expected to be people who care about the law and to care about the environment in a way not hesitate to provide information and testimony to the police if there is a circulation of drugs or pharmaceutical products that require a marketing authorization from the Government.

\section{Bibliography}

[1] Titon Slamet Kurnia, 2007, Hak Atas Drajat Kesehatan Optimal Sebagai HAM di Indonesia, Alumni, Bandung

[2] Amri Amir, 1997Bunga Ranpai Hukum Kesehatan, Widya Medika, Jakarta,

[3] Chairul Huda, 2006, Tiada Pidana Tanpa Kesalahan Menuju kepada Tiada PertanggungJawaban Pidana Tanpa Kesalahan, Prenada Media, Jakarta

[4] Hari Sasangka dan Lily Rosita, 2003, Hukum Pembuktian dalam Perkara Pidana, Bandung: Mandar Maju. 